\title{
G-quadruplex: Mục tiêu tiềm năng cho những phân tử nhỏ và protein trong việc tạo thuốc trị ung thư
}

\section{G-quadruplex: A potential target for small molecules and proteins in anti-cancer drug investigation}

\author{
Đặng Thanh Dũng ${ }^{1 *}$, Nguyễn Thị Thu Thảo ${ }^{1}$ \\ ${ }^{1}$ Trường Đại học Mở Thành phố Hồ Chí Minh, Việt Nam \\ *Tác giả liên hệ, Email: dung.dthanh@ou.edu.vn
}

THÔNG TIN
DOI: 10.46223/HCMCOUJS
tech.vi.13.1.793.2018
Ngày nhận: 02/04/2018
Ngày nhận lại: 07/06/2018
Duyệt đăng: 10/07/2018

Tù khóa:

G-quadruplex, protein, phân tử nhỏ, ung thư

\section{TÓM TẮT}

G-quadruplex DNA hay RNA là cấu trúc bậc hai xuất hiện ở những vùng giàu Guanine có cấu trúc 4 sợi được hình thành bởi những G-tetrad xếp chồng lên nhau. Sự hình thành cấu trúc G-quadruplex trong DNA hay RNA đóng vai trò quan trọng trong các quá trình sinh học của tế bào như: sao chép DNA, phiên mã, dịch mã và đặc biệt trong quá trình kéo dài của telomer. Do đó, G-quadruplex được xem là mục tiêu quan trọng cho các quá trình điều hòa và kiểm soát các hoạt động của tế bào có liên quan gen. Hiện nay, hầu hết những hoạt động bất thường của gen đều có ảnh hưởng trực tiếp đến quá trình gây ra bệnh ung thư. Hiểu và kiểm soát được quá trình hình thành G-quadruplex là một trong những hướng để tìm ra cách chữa trị ung thư. Chính vì vậy, việc nghiên cứu, phát triển những phân tử nhỏ hay protein có tương tác trực tiếp với G-quadruplex sẽ đóng vai trò quan trọng trong việc điều chế thuốc chữa các bệnh ung thư và hơn nữa phương pháp điều trị ung thư hướng mục tiêu hiện đang là tâm điểm của nhiều nghiên cứu. Trong bài báo này, chúng tôi tập trung phân tích và thảo luận về sự tương tác giữa các phân tử nhỏ hay protein với G-quadruplex cũng như đánh giá tiềm năng của các ligands trong việc điều trị ung thư.

ABSTRACT
DNA or RNA G-quadruplexes are secondary structures that
occur in four-stranded Guanine-rich regions formed by stacked
G-tetrads. The formation of DNA or RNA G-quadruplex
structures plays a key role in many cellular biological processes
such as DNA replication, transcription, translation, and telomeric
maintenance. As such, G-quadruplex is considered a potential
target for the regulation of genes in cellular processes. Most of
the abnormal gene activities cause cancer. Understanding and


Keywords:

G-quadruplex, proteins, small molecules, cancer controlling the formation of G-quadruplex is one of the approaches for cancer treatment. Therefore, research and development of small molecules or proteins that can directly target G-quadruplex will play a key role in the development of cancer treatments and further therapeutic approaches. In this research, we will focus on analysis and discussion of the interaction between G-quadruplex and its ligands (small molecules or proteins) as well as the potentials of these ligands in cancer treatment.

\section{Giới thiệu}

DNA thường được xem như là 1 phân tử xoắn kép có 2 sợi tự bắt cặp bổ sung với nhau bằng các cặp bazơ (A-T, G-C) theo mô hình Watson-Crick. Tuy nhiên, những trình tự DNA hay RNA giàu purine và chứa nhiều guanine $(\mathrm{G})$ liên tục có thể hình thành cấu trúc 4 sợi được gọi là G-quadruplex (Gellert, Lipsett, \& Davies, 1962; Sen \& Gilbert, 1988; Smith \& Feigon, 1992). G-quadruplex có cấu trúc đa hình khác nhau: 4 sợi của lõi G-tetrad có thể xếp song song (theo cùng một hướng) hoặc là không song song được chia làm 2 dạng: (1) 3 sợi chạy cùng hướng và sợi còn lại chạy ngược hướng, (2) 2 sợi chạy cùng hướng và 2 sợi còn lại chạy ngược hướng (Hình 1B) (Wang \& Patel, 1993). G-quadruplex được ổn định bởi ion dương hóa trị một như $\mathrm{K}^{+}$hoặc $\mathrm{Na}^{+}$nên giữa các mặt phẳng của G-tetrads là không gian cho ion dương như $\mathrm{K}^{+}$và $\mathrm{Na}^{+}$được phối hợp bởi lực hút tĩnh điện mạnh của tám gốc phân tử carbonyl (F. M. Chen, 1992; Laughlan et al., 1994).
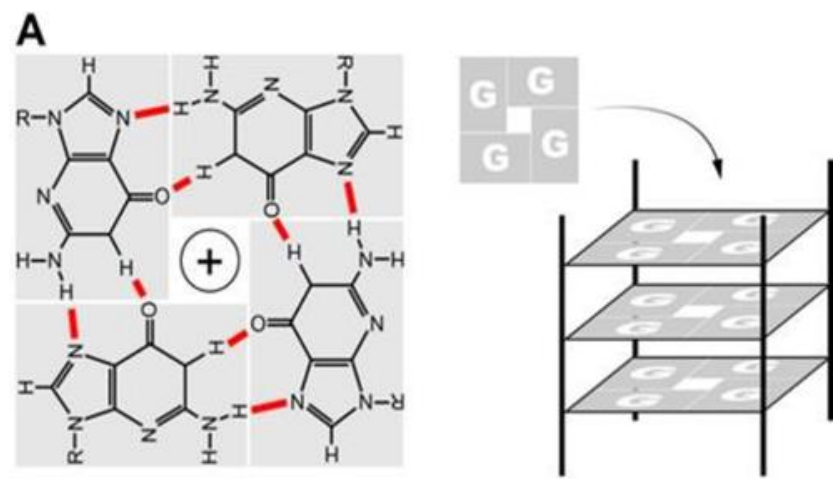

B
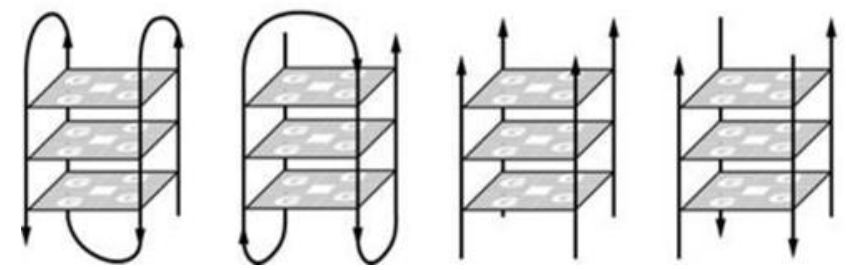

Hình 1. Cấu trúc của G-quadruplex. A) Cấu trúc G-quadruplex được hình thành trong DNA hay RNA với sự hiện diện của ion dương $\mathrm{K}^{+}$hoặc $\mathrm{Na}^{+}$. B) G-quadruplex với những cấu trúc hay hình dạng khác nhau: song song và không song song 
Theo mô phỏng bởi phần mềm máy tính thì có khoảng 300.000 trình tự có thể hình thành cấu trúc G-quadruplex trong bộ gene người (Rhodes \& Lipps, 2015; Vicki et al., 2015; Zlotorynski, 2015). G-quadruplex cũng hiện diện trong DNA của vi khuẩn hay RNA của virus và của người (Norseen, Johnson, \& Lieberman, 2009; Sundquist \& Heaphy, 1993). Trong bộ gene, G-quadruplex tồn tại nhiều ở các telomere nơi chứa khoảng 5.000 đến 10.000 trình tự lập lại giàu Guanine (TTAGGG) (Luu, Phan, Kuryavyi, Lacroix, \& Patel, 2006; Ma, Che, \& Yan, 2009; Neidle, 2003; Parkinson, Lee, \& Neidle, 2002; Phan, Kuryavyi, Luu, \& Patel, 2007; Phan, Luu, \& Patel, 2006). Bên cạnh đó, G-quadruplex cũng tồn tại trong promoter của một số gene (Balasubramanian, Hurley, \& Neidle, 2011; Cogoi \& Xodo, 2006; Patel, Phan, \& Kuryavyi, 2007). Trong RNA, G-quadruplex được tìm thấy trong những vùng không dịch mã của RNA thông tin (Bugaut \& Balasubramanian, 2012; Patel et al., 2007). Sản phẩm phiên mã từ telomere, TERRA, cũng có thể hình thành nên cấu trúc G-quadruplex (Lu et al., 2011; Martadinata, Heddi, Lim, \& Phan, 2011; Takahama et al., 2013). Trong hệ thống tế bào, sự hình thành G-quadruplex có liên quan đến nhiều quá trình sinh học như sự duy trì telomere, sao chép, phiên mã và dịch mã (Rhodes \& Lipps, 2015) (Hình 2).

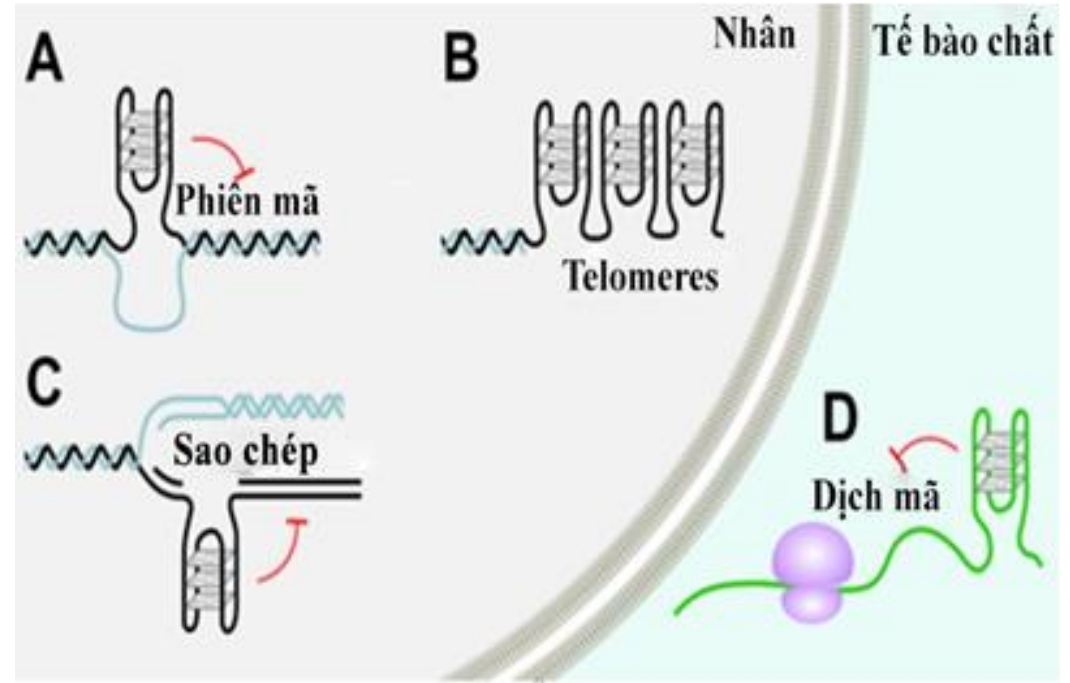

Hình 2. Sự hình thành cấu trúc G-quadruplex trong quá trình sinh học: A) Phiên mã, B) Duy trì telomere, C) Sao chép DNA và D) Dịch mã (Rhodes \& Lipps, 2015)

Trong các nhiễm sắc thể người, sợi đơn ở đầu 3' của telomer (khoảng 100 đến 280 nt) được cho là rất thuận lợi để hình thành cấu trúc G-quadruplex. Việc hình thành cấu trúc Gquadruplex có thể gây ức chế hoạt tính của telomerase, dẫn đến telomere càng lúc càng ngắn lại (F. M. Chen, 1992; Gomez et al., 2004; Laughlan et al., 1994; Mergny \& Helene, 1998). Kiểm soát chiều dài của telomere gần đây được xem là chìa khóa trong liệu pháp chữa trị ung thư. Ngoài ra, G-quadruplex cũng có vai trò quan trọng trong phiên mã và dịch mã. Có khoảng $50 \%$ gene người có cấu trúc G-quadruplex gần vùng promoter liên quan đến điều hòa biểu hiện của gen (Z. Chen, Xiu, Li, \& Xu, 2010). Kiểm soát cũng như làm ổn định cấu trúc G-quadruplex bởi những phân tử nhỏ hay protein là tiền đề quan trọng điều hòa các quá trình sinh học của tế bào. Trong bài báo này, chúng tôi phân tích và thảo luận về sự tương tác giữa các phân tử nhỏ hay protein với G-quadruplex cũng như tiềm năng của chúng trong việc điều trị ung thư. 


\section{Sự tương giữa G-quadruplex và protein}

G-quadruplex có thể được xem là mục tiêu cho sự tương tác đặc hiệu với protein trong các quá trình sinh học. Trong hoạt động tế bào, hệ thống protein được tổng hợp để nhận diện và tháo xoắn cấu trúc G-quadruplex. Hệ thống protein này thuộc nhóm helicase (Vaughn et al., 2005). Ở người, protein RHAU gồm có 1008 amino acids. RHAU là protein thuộc nhóm RNA helicase có liên kết với vùng trình tự giàu Adenine và Uracil của RNA (Lattmann, Stadler, Vaughn, Akman, \& Nagamine, 2011; Vaughn et al., 2005) (Hình 3). Khi tế bào chịu ái lực căng thẳng (stress), protein RHAU sẽ liên kết với RNA thông tin (mRNA) và tạo thành phức hợp protein và RNA có nồng độ cao để giúp bảo vệ RNA khỏi bị phân hủy từ những điều kiện không thuận lợi đối với tế bào (Chalupnikova et al., 2008). Ngoài ra, những nghiên cứu gần đây cho thấy protein RHAU có vai trò quan trọng trong việc nhận diện và bám vào mục tiêu cấu trúc song song DNA và RNA G-quadruplex và protein RHAU thực hiện chức năng là mở xoắn cấu trúc G-quadruplex này trong điều kiện có sự hiện diện của ATP (Lattmann et al., 2011).

RHAU

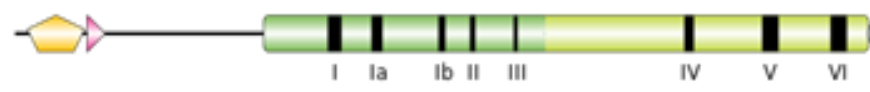

Gly-rich (aa. 10-51)

RSM (aa. 54-66)

Hình 3. Protein RHAU ở người gồm có 1008 amino acid chứa các đoạn helicase tập trung ở đầu $\mathrm{C}$, và chứa trình tự RSM bám đặc hiệu vào G-quadruplex ở đầu $\mathrm{N}$

Protein RHAU nhận diện và bám vào cả DNA và RNA với áp lực cao thông qua trình tự peptide đặc hiệu ngắn (RSM, RHAU 54-66) ở vùng đầu N của protein (Lattmann, Giri, Vaughn, Akman, \& Nagamine, 2010). Đoạn RHAU peptide này đủ khả năng nhận biết và bám đặc hiệu vào cấu trúc song song của G-quadruplex DNA hoặc RNA. Nghiên cứu về cấu trúc của phức hợp giữa đoạn RHAU peptide dài 18 amino acid ở đầu $\mathrm{N}$ (có chứa trình tự bám đặc hiệu) với G-quadruplex (T95-2T) đã cho thấy cơ chế bám của peptide này vào G-quadruplex (Heddi, Cheong, Martadinata, \& Phan, 2015). RHAU peptide bám bao phủ bề mặt G-tetrad và kẹp vào G-quadruplex bằng tương tác tĩnh điện giữa những nhóm phosphate của DNA và những amino acid mang điện tích dương (Hình 4) (Heddi et al., 2015). Với các đặc tính vật lý này, RHAU peptide có thể được xem là phân tử ligand tiềm năng đặc hiệu cho cấu trúc G-quadruplex song song. 


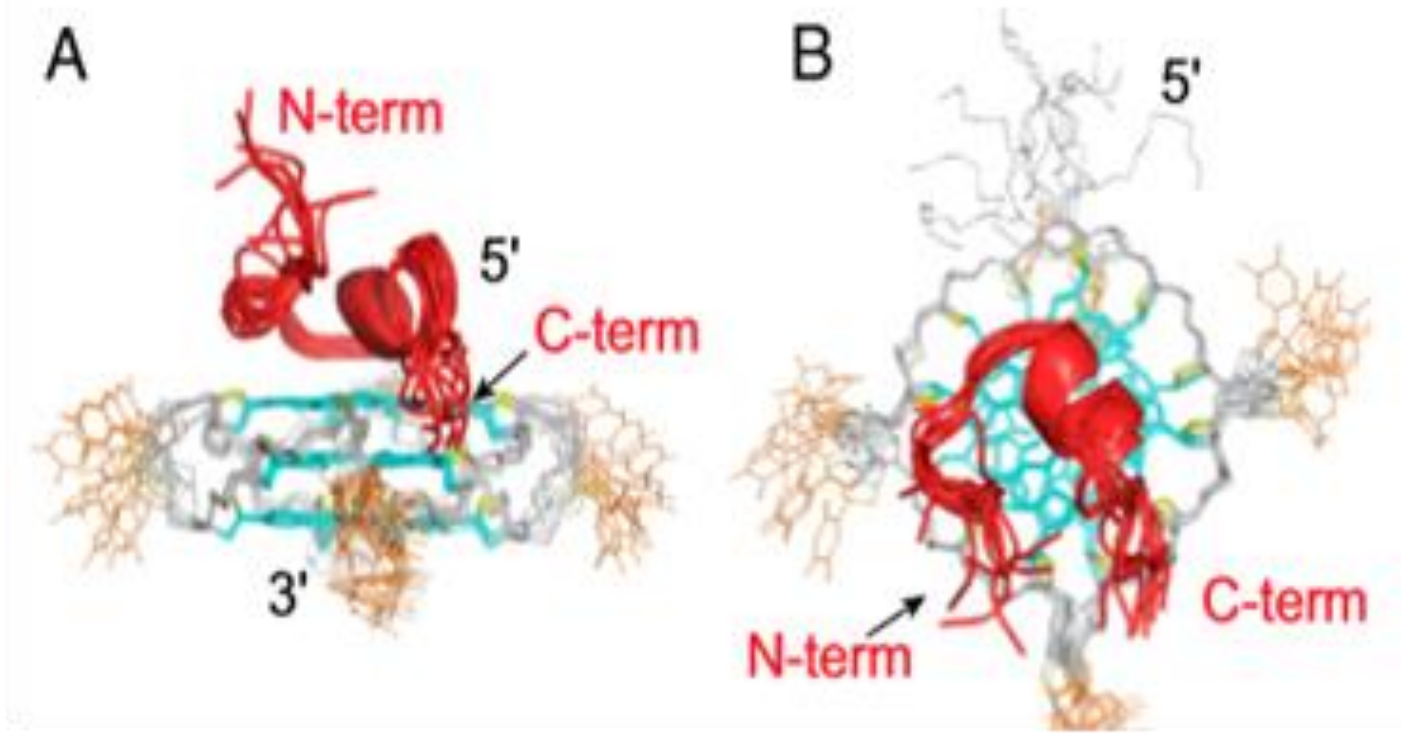

Hình 4. Nghiên cứu về cấu trúc của phức hợp RHAU peptide (18 amino acids) và Gquadruplex (T95-2T). A) góc nhìn bên cạnh và B) Sự tương tác phân tử giữa peptide và những guanine của DNA của đầu 5' G-tetrad, các mạch nhánh mang điện tích dương của các amino acid và khung phosphate của DNA (Heddi, 2015)

Đoạn ngắn peptide RHAU còn được ứng dụng trong việc phát hiện cấu trúc của Gquadruplex. Để nghiên cứu chức năng của G-quadruplex cũng như điều hòa kiểm soát cấu trúc này, việc phát hiện sự hình thành G-quadruplex trong in vitro và in vivo là rất cần thiết. Chính vì vậy, Dang và Phan (Dang \& Phan, 2016) đã sử dụng kỹ thuật protein tái tổ hợp để tạo ra những protein dò huỳnh quang RHAU-CFP bằng cách dung hợp giữa protein CFP (cyan fluorescent protein) và các đoạn ngắn khác nhau của peptide RHAU (Hình 5).

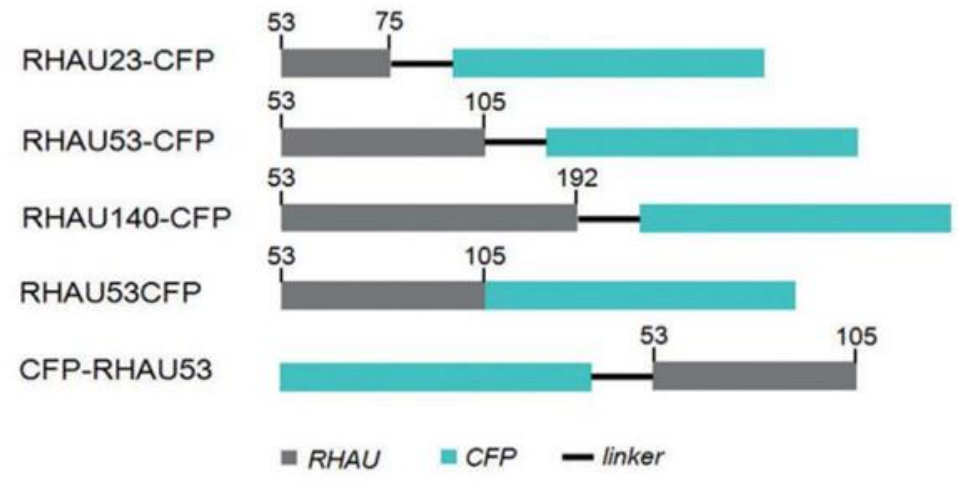

Hình 5. Xây dựng những mẫu dò protein huỳnh quang nhận biết đặc hiệu G-quadruplex. Nhũng peptide RHAU có chiều dài khác nhau ( 23 aa, 53 aa và 140 aa) được dung hợp với protein huỳnh quang CFP

RHAU-CFP cho tương tác đặc hiệu với cấu trúc G-quadruplex song song với ái lực cao (Hình 6). Điều thú vị là mẫu dò RHAU-CFP huỳnh quang có thể nhận biết được cấu trúc Gquadruplex song song bằng mắt thường (kết quả hình ảnh không được trình bày). 
a)

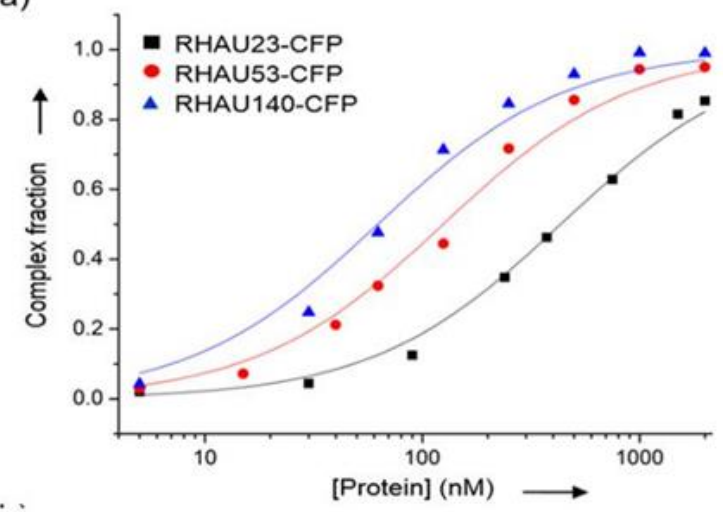

b)

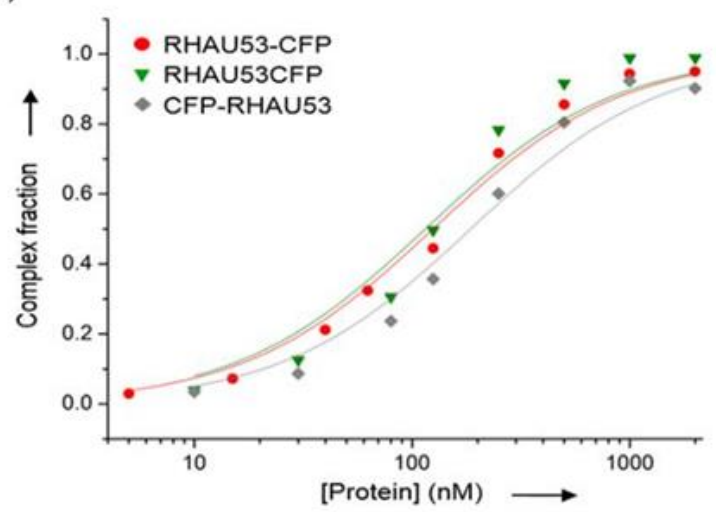

Hình 6. Ái lực bám của mẫu dò huỳnh quang đối với cấu trúc G-quadruplex song song. Đồ thị được dựng và giá trị ái lực bám $(\mathrm{Kd})$ được tính dựa vào phần mềm origin 8 (RHAU23CFP Kd=433nM; RHAU53-CFP Kd=124nM; RHAU140-CFP Kd=62mM, RHAU53CFP (without linker) $\mathrm{Kd}=115 \mathrm{nM}$; CFP-RHAU53 $\mathrm{Kd}=185 \mathrm{nM}$ )

Nghiên cứu tạo ra những protein mới bám đặc hiệu vào cấu trúc G-quadruplex đang được quan tâm hiện nay. Kháng thể (BG4) bám đặc hiệu với G-quadruplex đã được tạo ra khi sử dụng công nghệ phage display (Biffi, Tannahill, McCafferty, \& Balasubramanian, 2013b; Biffi, Tannahill, Miller, Howat, \& Balasubramanian, 2014). Kháng thể BG4 có thể nhận biết và bám đặc hiệu các G-quadruplex với ái lực cao với hằng số phân ly $\mathrm{Kd}$ khoảng $1 \mathrm{nM}$. BG4 được ứng dụng cho việc phát hiện sự hình thành G-quadruplex trong các giai đoạn phân chia của tế bào người. Kết quả chứng minh được khả năng tự hình thành cấu trúc $\mathrm{G}$-quadruplex trong bộ gene người ở những chu kỳ khác nhau của tế bào. Từ đó có thể xác định vị trí của cấu trúc G-quadruplex trong hệ thống bộ gen, cung cấp một cơ sở quan trọng giúp củng cố vai trò sinh học và tiềm năng quan trọng của cấu trúc G-quadruplex.
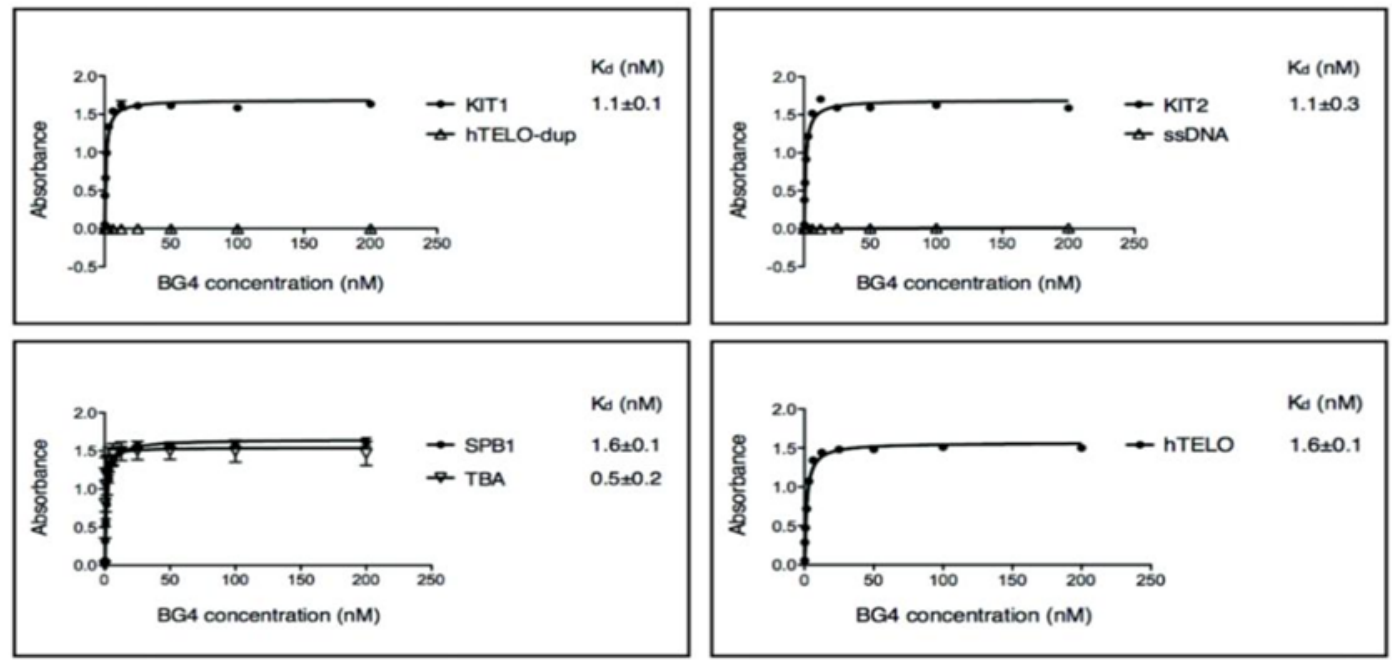

Hình 7. Ái lực bám đặc hiệu của kháng thể BG4 đối với các G-quadruplex khác nhau (Biffi, Tannahill, McCafferty, \& Balasubramanian, 2013a) 
Kháng thể BG4 bám đặc hiệu G-quadruplex với ái lực rất cao, đây được xem là ưu thế của kháng thể này trong việc làm ổn định cấu trúc của G-quadruplex trong tế bào. Tuy nhiên, kích thước lớn của kháng thể gây bất lợi trong thao tác cũng như trong việc vận chuyển nội bào nhằm ứng dụng kiểm soát các quá trình sinh học. Chính vì vậy, hiện nay nhóm chúng tôi đang nghiên cứu tạo ra những đoạn peptide ngắn bám đặc hiệu G-quadruplex với ái lực cao. Đây cũng được xem là hướng nghiên cứu tiềm năng trong lĩnh vực phát triển peptide dùng như thuốc trong việc điều trị ung thư.

\section{Sự tương tác giữa G-quadruplex và những phân tử nhỏ}

Gần đây G-quadruplex được tiếp cận như một mục tiêu cho việc nghiên cứu và phát triển những phân tử nhỏ có khả năng bám đặc hiệu vào cấu trúc G-quadruplex này. Sự hình thành cấu trúc G-quadruplex gây ảnh hưởng đến các quá trình sinh học như duy trì telomere, sao chép, phiên mã và dịch mã. Cụ thể, sự hình thành G-quadruplex ở đầu 3' của telomere sẽ ngăn cản sự bám của enzyme telomerase vào telomere, dẫn đến kết quả là ngăn cản sự kéo dài của telomere (Paeschke, Simonsson, Postberg, Rhodes, \& Lipps, 2005; Sissi \& Palumbo, 2014; Tan, Tang, Kan, \& Hao, 2015). Sự ức chế của các quá trình kéo dài telomere, sao chép, phiên mã và dịch mã rõ ràng là liên quan rất nhiều vào các quá trình tuổi thọ cũng như phát triển ung thư. Do đó, kiểm soát (có tính chất đặc hiệu) sự hình thành cấu trúc G-quadruplex sẽ giúp tạo ra những phương pháp hữu ích cho việc phát triển thuốc đặc hiệu với G-quadruplex. Nghiên cứu phát triển những phân tử nhỏ có khả năng tương tác đặc hiệu và ái lực cao với G-quadruplex sẽ tạo ra những thuốc cho việc chữa trị bệnh ung thư. Cụ thể, những phân tử nhỏ có khả năng bám đặc hiệu và ổn định cấu trúc G-quadruplex có thể được sàng lọc nhằm ứng dụng ức chế quá trình kéo dài telomere, phiên mã và dịch mã của gene, dẫn đến kết quả là tiêu diệt tế bào ung thư (Hình 8) (De Cian et al., 2007; Salvati et al., 2007; Sissi \& Palumbo, 2014).

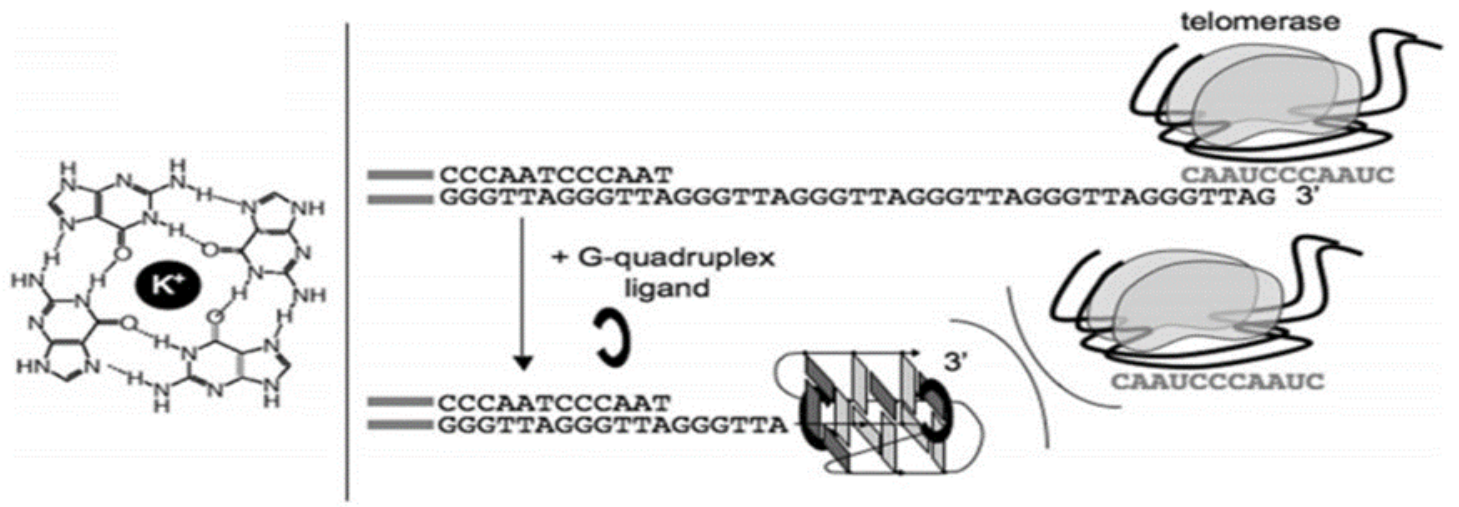

Hình 8. Sự ức chế enzyme telomerase bởi những phân tử nhỏ (ligands). Hình ảnh mô tả Gquartet (trái) và sự ức chế telomerase trực tiếp bởi những phân tử nhỏ bám vào cấu trúc Gquadruplex (phải) (De Cian et al., 2007)

Hiện nay, trên thế giới đã có nhiều nghiên cứu và phát triển những phân tử nhỏ có khả năng bám vào G-quadruplex như: CX-3543, piper, piper derivatives, TMPyP4, Hoechst 33258, $\mathrm{S}_{\mathrm{e} 2} \mathrm{SAP},\left[\mathrm{Pt}(\mathrm{Dip})_{2}\right]\left(\mathrm{P}_{\mathrm{F} 6) 2}\right.$ và Quindolines (Duchler, 2012). Trong đó, TMPyp4 được xem là ligand tiêu biểu cho G-quaduplex và được chú trọng nhiều hơn vì những đặc tính vật lý cũng như hóa học của chúng như bề mặt lớn, những vòng đối xứng và dễ tối ưu hóa để có thể tương tác tốt 
hơn trên bề mặt của G-tetrad. Những phân tử nhỏ có khả năng bám và làm ổn định cấu trúc Gquadruplex ngày càng được phát triển với số lượng lớn và những ứng dụng khác nhau (Bảng 1 ) (Duchler, 2012).

\section{Bảng 1}

Những phân tử nhỏ có khả năng bám và ổn định cấu trúc G-quadruplex. Một vài mục tiêu và ảnh hưởng của những phân tử nhỏ đã được nghiên cứu (Duchler, 2012)

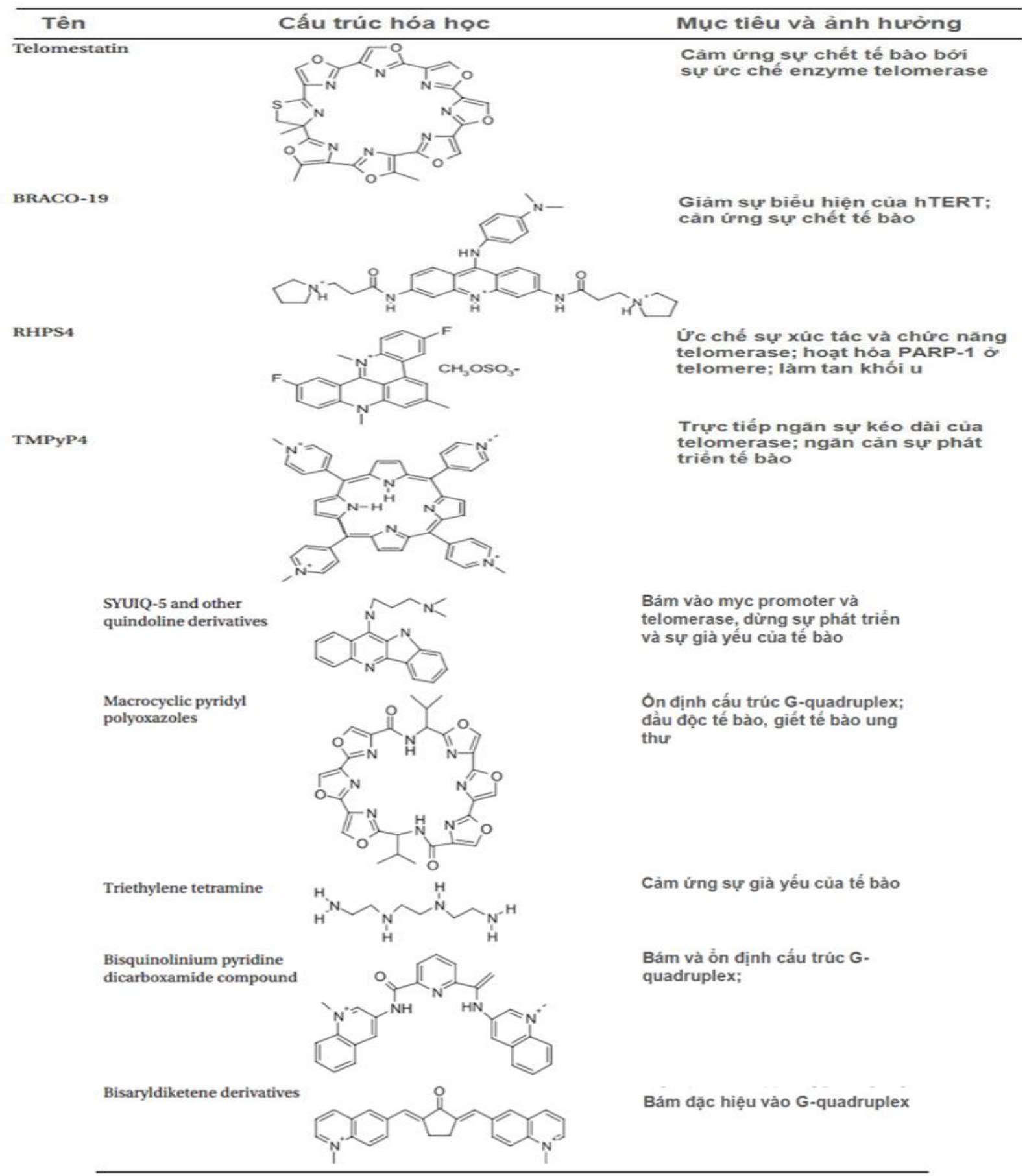

Nguồn: Kết quả phân tích dữ liệu của nhóm nghiên cứu 
Những phân tử nhỏ này có thể được sử dụng như sản phẩm thuốc tiềm năng trong việc ức chế sự biểu hiện gene và sự kéo dài telomer (Han \& Hurley, 2000; Mergny \& Helene, 1998). Tuy nhiên, những phân tử này còn có mặt hạn chế vì ảnh hưởng phụ gây độc với tế bào và khả năng phân biệt cấu trúc G-quadruplex đa hình khác nhau còn kém. Sàng lọc hay tổng hợp những phân tử nhỏ có tương tác đặc hiệu và làm ổn định cấu trúc G-quadruplex đang rất được quan tâm hiện nay cho ứng dụng trong điều chế thuốc chữa trị ung thư.

\section{Kết luận}

Sự hình thành G-quadruplexes đóng vai trò quan trọng trong các quá trình sinh học của tế bào như: sao chép DNA, phiên mã, dịch mã và ức chế sự kéo dài của telomere. Kiểm soát được sự hình thành G-quadruplex được xem là nhân tố quan trọng trong việc kiểm soát quá trình hoạt động của tế bào. Đặc biệt sự ức chế các quá trình phiên mã, dịch mã và kéo dài telomere đóng vai trò quan trọng trong việc ức chế sự phát triển của ung thư. Do đó, cấu trúc G-quadruplex được xem là mục tiêu tiềm năng cho việc phát triển các phân tử nhỏ hay protein có khả năng bám đặc hiệu vào cấu trúc này. Hiện nay chỉ một số lượng ít các phân tử nhỏ hay protein đã được tìm ra có khả năng bám đặc hiệu vào G-quadruplex, tuy nhiên phần lớn các phân tử này còn nhiều mặt hạn chế về những tác dụng phụ và mức độ bám đặc hiệu cũng như ái lực bám chưa cao hoặc kích thước lớn. Do đó việc sàng lọc, tổng hợp những phân tử nhỏ hay protein bám đặc hiệu các dạng G-quaduplex khác nhau với ái lực cao được xem là hướng nghiên cứu tiềm năng nhằm tạo ra và phát triển những sản phẩm thuốc có thể điều trị các bệnh ung thư.

\section{LÒ̀I CÁM ƠN}

Nghiên cứu này được tài trợ bởi Quỹ Phát triển khoa học và công nghệ Quốc gia (NAFOSTED) trong đề tài mã số 108.02-2017.305.

\section{Tài liệu tham khảo}

Balasubramanian, S., Hurley, L. H., \& Neidle, S. (2011). Targeting G-quadruplexes in gene promoters: A novel anticancer strategy? Nature Reviews Drug Discovery, 10(4), 261-275. doi:10.1038/Nrd3428

Biffi, G., Tannahill, D., McCafferty, J., \& Balasubramanian, S. (2013a). Quantitative visualization of DNA G-quadruplex structures in human cells. Nature Chemistry, 5(3), 182-186. doi:10.1038/nchem.1548

Biffi, G., Tannahill, D., McCafferty, J., \& Balasubramanian, S. (2013b). Quantitative visualization of DNA G-quadruplex structures in human cells. Nature Chemistry, 5(3), 182-186. doi:10.1038/Nchem.1548

Biffi, G., Tannahill, D., Miller, J., Howat, W. J., \& Balasubramanian, S. (2014). Elevated levels of G-quadruplex formation in human stomach and liver cancer tissues. PLoS One, 9(7), Article e102711. doi:10.1371/journal.pone.0102711

Bugaut, A., \& Balasubramanian, S. (2012). 5 '-UTR RNA G-quadruplexes: Translation regulation and targeting. Nucleic Acids Research, 40(11), 4727-4741. doi:10.1093/Nar/Gks068 
Chalupnikova, K., Lattmann, S., Selak, N., Iwamoto, F., Fujiki, Y., \& Nagamine, Y. (2008). Recruitment of the RNA Helicase RHAU to stress granules via a unique RNA-binding domain. Journal of Biological Chemistry, 283(50), 35186-35198. doi:10.1074/jbc.M804857200

Chen, F. M. (1992). Sr2+ facilitates intermolecular G-quadruplex formation of telomeric sequences. Biochemistry, 31(15), 3769-3776.

Chen, Z., Xiu, M. H., Li, S. F., \& Xu, M. (2010). The biological functions of G-quadruplex. Sheng Li Ke Xue Jin Zhan, 41(5), 329-334.

Cogoi, S., \& Xodo, L. E. (2006). G-quadruplex formation within the promoter of the KRAS proto-oncogene and its effect on transcription. Nucleic Acids Research, 34(9), 2536-2549. doi:10.1093/Nar/Gk1286

Dang, D. T., \& Phan, A. T. (2016). Development of fluorescent protein probes specific for parallel DNA and RNA G-quadruplexes. Chembiochem, 17(1), 42-45.

De Cian, G. C. A., Reichenbach, P., De Lemos, E., Monchaud, D., \& Teulade-Fichou, M.-P., Shin-ya, K., ... Mergny, J.-L. (2007). Reevaluation of telomerase inhibition by quadruplex ligands and their mechanisms of action. PNAS, 104, 17347-17352.

Duchler, M. (2012). G-quadruplexes: Targets and tools in anticancer drug design. Journal of Drug Targeting, 20(5), 389-400. doi:10.3109/1061186x.2012.669384

Gellert, M., Lipsett, M. N., \& Davies, D. R. (1962). Helix formation by guanylic acid. Proceedings of the National Academy of Sciences of the United States of America, 48(12), 2013-2018. doi:10.1073/pnas.48.12.2013

Gomez, D., Lemarteleur, T., Lacroix, L., Mailliet, P., Mergny, J. L., \& Riou, J. F. (2004). Telomerase downregulation induced by the G-quadruplex ligand 12459 in A549 cells is mediated by hTERT RNA alternative splicing. Nucleic Acids Research, 32(1), 371-379. doi:10.1093/nar/gkh181

Han, H., \& Hurley, L. H. (2000). G-quadruplex DNA: A potential target for anti-cancer drug design. Trends in Pharmacological Sciences, 21(4), 136-142.

Heddi, B., Cheong, V. V., Martadinata, H., \& Phan, A. T. (2015). Insights into G-quadruplex specific recognition by the DEAH-box helicase RHAU: Solution structure of a peptidequadruplex complex. Submitted, 112(31), 9608-9613.

Lattmann, S., Giri, B., Vaughn, J. P., Akman, S. A., \& Nagamine, Y. (2010). Role of the amino terminal RHAU - Specific motif in the recognition and resolution of guanine quadruplexRNA by the DEAH-box RNA helicase RHAU. Nucleic Acids Research, 38(18), 62196233. doi:10.1093/Nar/Gkq372

Lattmann, S., Stadler, M. B., Vaughn, J. P., Akman, S. A., \& Nagamine, Y. (2011). The DEAHbox RNA helicase RHAU binds an intramolecular RNA G-quadruplex in TERC and associates with telomerase holoenzyme. Nucleic Acids Research, 39(21), 9390-9404. doi:10.1093/Nar/Gkr630

Laughlan, G., Murchie, A. I. H., Norman, D. G., Moore, M. H., Moody, P. C. E., Lilley, D. M. J., \& Luisi, B. (1994). The high-resolution crystal-structure of a parallel-stranded guanine tetraplex. Science, 265(5171), 520-524. doi:10.1126/science.8036494 
Lu, Y. J., Yan, S. C., Chan, F. Y., Zou, L., Chung, W. H., Wong, W. L., . . Wong, K. Y. (2011). Benzothiazole - substituted benzofuroquinolinium dye: A selective switch-on fluorescent probe for G-quadruplex. Chemical Communications, 47(17), 4971-4973. doi:10.1039/C1cc00020a

Luu, K. N., Phan, A. T., Kuryavyi, V., Lacroix, L., \& Patel, D. J. (2006). Structure of the human telomere in K+ solution: An intramolecular $(3+1) \mathrm{G}$-quadruplex scaffold. Journal of the American Chemical Society, 128(30), 9963-9970. doi:10.1021/Ja062791w

Ma, D. L., Che, C. M., \& Yan, S. C. (2009). Platinum(II) complexes with dipyridophenazine ligands as human telomerase inhibitors and luminescent probes for G-Quadruplex DNA. Journal of the American Chemical Society, 131(5), 1835-1846. doi:10.1021/Ja806045x

Martadinata, H., Heddi, B., Lim, K. W., \& Phan, A. T. (2011). Structure of long human telomeric RNA (TERRA): G-Quadruplexes formed by four and eight UUAGGG repeats are stable building blocks. Biochemistry, 50(29), 6455-6461. doi:10.1021/Bi200569f

Mergny, J. L., \& Helene, C. (1998). G-quadruplex DNA: A target for drug design. Nature Medicine, 4(12), 1366-1367. doi:10.1038/3949

Neidle, S. (2003). G-quadruplex formation at telomere ends: A strategy for selective interference with telomere maintenance in tumour cells. British Journal of Cancer, 88, S5-S5.

Norseen, J., Johnson, F. B., \& Lieberman, P. M. (2009). Role for G-quadruplex RNA binding by Epstein-Barr virus nuclear antigen 1 in DNA replication and metaphase chromosome attachment. Journal of Virology, 83, 10336-10346.

Paeschke, K., Simonsson, T., Postberg, J., Rhodes, D., \& Lipps, H. J. (2005). Telomere endbinding proteins control the formation of G-quadruplex DNA structures in vivo. Nature Structural \& Molecular Biology, 12(10), 847-854. doi:10.1038/nsmb982

Parkinson, G. N., Lee, M. P. H., \& Neidle, S. (2002). Crystal structure of parallel quadruplexes from human telomeric DNA. Nature, 417(6891), 876-880. doi:10.1038/Nature755

Patel, D. J., Phan, A. T., \& Kuryavyi, V. (2007). Human telomere, oncogenic promoter and 5'UTR G-quadruplexes: Diverse higher order DNA and RNA targets for cancer therapeutics. Nucleic Acids Research, 35(22), 7429-7455. doi:10.1093/Nar/Gkm711

Phan, A. T., Kuryavyi, V., Luu, K. N., \& Patel, D. J. (2007). Structure of two intramolecular G-quadruplexes formed by natural human telomere sequences in $\mathrm{K}+$ solution. Nucleic Acids Research, 35(19), 6517-6525. doi:10.1093/Nar/Gkm706

Phan, A. T., Luu, K. N., \& Patel, D. J. (2006). Different loop arrangements of intramolecular human telomeric (3+1) G-quadruplexes in K+ solution. Nucleic Acids Research, 34(19), 5715-5719. doi:10.1093/Nar/Gkl726

Rhodes, D., \& Lipps, H. J. (2015). G-quadruplexes and their regulatory roles in biology. Nucleic Acids Research, 43(18), 8627-8637.

Salvati, E., Leonetti, C., Rizzo, A., Scarsella, M., Mottolese, M., Galati, R., . . Biroccio, A. (2007). Telomere damage induced by the G-quadruplex ligand RHPS4 has an antitumor effect. Journal of Clinical Investigation, 117(11), 3236-3247. doi:10.1172/JCI32461 
Sen, D., \& Gilbert, W. (1988). Formation of parallel 4-stranded complexes by guanine-rich motifs in DNA and its implications for meiosis. Nature, 334(6180), 364-366. doi: $10.1038 / 334364 \mathrm{a} 0$

Sissi, C., \& Palumbo, M. (2014). Telomeric G-quadruplex architecture and interactions with potential drugs. Current Pharmaceutical Design, 20(41), 6489-6509.

Smith, F. W., \& Feigon, J. (1992). Quadruplex structure of oxytricha telomeric DNA oligonucleotides. Nature, 356(6365), 164-168.

Sundquist, W. I., \& Heaphy, S. (1993). Evidence for interstrand quadruplex formation in the dimerization of human immunodefiiency virus 1 genomic RNA. Proceedings of the National Academy of Sciences of the United States of America, 90, 3393-3397.

Takahama, K., Takada, A., Tada, S., Shimizu, M., Sayama, K., Kurokawa, R., \& Oyoshi, T. (2013). Regulation of telomere length by G-quadruplex telomere DNA- and TERRAbinding protein TLS/FUS. Chemistry \& Biology, 20(3), 341-350. doi:10.1016/j.chembiol.2013.02.013

Tan, Z., Tang, J., Kan, Z. Y., \& Hao, Y. H. (2015). Telomere G-Quadruplex as a potential target to accelerate telomere shortening by expanding the incomplete end-replication of telomere DNA. Current Topics in Medicinal Chemistry, 15(19), 1940-1946.

Vaughn, J. P., Creacy, S. D., Routh, E. D., Joyner-Butt, C., Jenkins, G. S., Pauli, S., . . Akman, S. A. (2005). The DEXH protein product of the DHX36 gene is the major source of tetramolecular quadruplex G4-DNA resolving activity in HeLa cell lysates. Journal of Biological Chemistry, 280(46), 38117-38120. doi:10.1074/jbc.C500348200

Vicki, S. C., Marsico, G., Boutell, J. M., Di Antonio, M., Smith, G. P., \& Balasubramanian, S. (2015). High-throughput sequencing of DNA G-quadruplex structures in the human genome. Nature Biotechnology, 33, 877-881.

Wang, Y., \& Patel, D. J. (1993). Solution structure of a parallel-stranded G-quadruplex DNA. Journal of Molecular Biology, 234(4), 1171-1183. doi:10.1006/jmbi.1993.1668

Zlotorynski, E. (2015). Mapping DNA G-quadruplex structures. Nature Reviews Molecular Cell Biology, 16, Article 518. 